Bangl. J. Vet. Med. (2010). 8(2): $107-115$

\title{
CLINICAL AND LABORATORY DIAGNOSES OF COMMON BACTERIAL DISEASES OF BROILER AND LAYER CHICKENS
}

\author{
A. K. M. Rakibul Hasan ${ }^{1}$, M. H. Ali ${ }^{1}$, M. P. Siddique ${ }^{1}$, M. M. Rahman ${ }^{1}$ and M. A. Islam ${ }^{1,2}$ \\ ${ }^{1}$ Department of Microbiology and Hygiene, Faculty of Veterinary Science, Bangladesh Agricultural University, \\ Mymensingh-2202 and ${ }^{2}$ School of Sustainable Agriculture, University Malaysia Sabah, 88999, \\ Kota Kinabalu, Sabah, Malaysia
}

\begin{abstract}
The study was undertaken with a view to compare clinical and laboratory diagnoses of various bacterial diseases of poultry during the period from March 2009 to February 2010 in the laboratory of the Dept. of Microbiology and Hygiene, Bangladesh Agricultural University (BAU), Mymensingh. A total of 135 sick and dead chickens (47 broilers and 88 layers) were collected from 12 different poultry farms (4 broilers and 8 layers) of Mymensingh and Gazipur districts which were subjected for clinical followed by laboratory diagnosis. Clinical diagnosis was made on the basis of clinical history, clinical signs and postmortem findings of the affected birds whereas; confirmatory diagnosis was made by using cultural examination, Gram's staining and different biochemical tests. In this study, out of 47 broilers, 16 (34\%) chickens were clinically diagnosed as colibacillosis, $11(23.40 \%)$ as salmonellosis and $2(4.25 \%)$ as fowl cholera. In the same way, out of 88 layer chickens, 28 (31.82\%) were diagnosed as colibacillosis, $16(18.18 \%)$ as salmonellosis and $11(12.50 \%)$ as fowl cholera. In laboratory, out of 47 suspected broiler chickens, 12 (25.53\%) chickens were diagnosed as colibacillosis, 7 (14.89\%) as salmonellosis and 0 $(0 \%)$ as fowl cholera. Correspondingly of the 88 layer chickens $22(25 \%)$ were diagnosed as colibacillosis, $11(13.64 \%)$ as salmonellosis and $8(9.09 \%)$ as fowl cholera. So the findings concluded that clinical diagnosis is not always accurate like laboratory diagnosis because in most cases clinical history, clinical signs and post-mortem lesions of different bacterial diseases including mixed infections are almost similar to other related diseases and it is recommended to confirm laboratory diagnosis before treatment of the diseases.
\end{abstract}

Key words: Colibacillosis, salmonellosis, fowl cholera, isolation, gram's staining, biochemical tests

\section{INTRODUCTION}

Development of poultry sector in Bangladesh is being hampered by a number of factors, of which the diseases are considered as the major factor causing 30\% mortality of chicken per year (Das et al., 2005). Important bacterial diseases of poultry in Bangladesh are pullorum disease (PD), fowl cholera (FC) and colibacillosis (Samad, 2000) which are responsible for high percentage of morbidity and mortality.

Escherichia coli is a common pathogen for commercial poultry causing colibacillosis all over the world. It is a major cause of respiratory and septicemic diseases in broiler chicken causing mortality less than $5 \%$ and morbidity over $50 \%$ but in layer it affects the reproductive tract resulting failure of egg productivity and fertility (Barens and Gross, 1997). It may cause about 28\% death in Sonali variety birds of Bangladesh (Biswas et al., 2006). E. coli infections cause many clinical manifestations such as airsacculitis, pericarditis, septicemia, and death of the birds (Hofstad et al., 1984). The infection has also been extended to various parts and organs such as skin, joints, eyes, head, blood, heart, yolk sac, peritoneum etc (Stebbins et al., 1992).

Salmonellosis is one of the most important bacterial diseases in poultry causing heavy economic losses through mortality and reduced meat and egg production (Haider et al., 2004). Avian salmonella infection occur in poultry either acute or chronic form by one or more member of the genus Salmonella, under the family Enterobacteriaceae (Hofstad et al., 1984). There are mainly two types of non-motile avian Salmonella spp. namely Salmonella gallinarum and Salmonella pullorum, are responsible for fowl typhoid (FT) and pullorum disease (PD) of poultry respectively. S. gallinarum and S. pullorum are short non flagellated, non spore forming, non capsulated, gram negative plump rods (Cheesbrough, 1984), capable of producing septicemic disease in most domestic and wild birds all over the world. Mortality in chickens has been reported 0 to $100 \%$ by PD and 10 to 93\% by FT. Increased mortality, anorexia, sudden drop in egg production and white or yellow diarrhea are the characteristic clinical signs of the diseases. The gross lesions in chicks are unabsorbed yolk sac and turbid yellow color fluids in the peritoneal cavity and in adult peritonitis, discrete, small, white necrotic foci in the liver and enteritis.

*Corresponding author: e-mail: alim_bau@yahoo.co.in 


\section{A. K. M. Rakibul Hasan and others}

Fowl cholera (FC), which is also known as avian cholera, avian pasteurellosis or avian hemorrhagic septicemia, is an infectious disease affecting domesticated and wild birds (Rimler and Glisson, 1997). It is caused by Pasteurella multocida, a gram negative, non-motile, non-spore forming rod occurring singly or in pairs, and occasionally in chains or filaments (Rimler and Glisson, 1997). FC can affect birds of any age, but it rarely occurs in commercial poultry of less than 8 weeks of age (Rimler, 1994). About 25\% to 35\% mortality in chickens accounted in Bangladesh is due to FC (Choudhury et al. 1985). Death of birds may be the first sign of FC while other signs are depression, diarrhea, ruffled feathers, increased respiratory rate, and cyanosis (Calnek et al., 1997). Commonly observed lesions are swollen liver with focal necrotic area and hemorrhage at the base of the heart, increased pericardial and peritoneal fluids (Calnek et al., 1997). At the field level in our country, most of the poultry diseases are diagnosed on the basis of symptoms and gross lesions which may aid to diagnose a disease but laboratory diagnosis is necessary for confirmation of the diseases (Banda, 2002).

Considering the above facts, the current study was undertaken with a view to compare the clinical (based on clinical signs and postmortem findings) and laboratory diagnoses (based on organism isolation-identification) of different bacterial diseases of poultry.

\section{MATERIALS AND METHODS}

The present study to compare between the clinical and laboratory diagnoses of different poultry diseases of Mymensingh and Gazipur districts was conducted during the period from March 2009 to February 2010 in the laboratory of the Department of Microbiology and Hygiene, Bangladesh Agricultural University, Mymensingh2202.

\section{Clinical diagnosis}

Clinical diagnosis was made on the basis of recorded clinical history from farm authority, observed clinical signs and gross pathological lesions of the dead and sick birds. A total of 135 (47 broiler of 1 to 6 weeks aged and 88 layer of 1 to $>15$ weeks aged) different aged sick and dead chickens were collected from 12 ( 4 broiler and 8 layer) farms. The bird was examined systematically and the observed postmortem changes were recorded during necropsy according the procedure described by Charlton (2000).

\section{Samples for the isolation of bacteria}

For isolation and identification of bacteria, different samples like liver, lung, heart, heart blood, spleen, peritoneal fluid, intestinal contents, tracheal swab, and egg follicles were collected from affected chickens.

\section{Laboratory diagnosis of bacterial diseases \\ Culture and morphological staining of bacteria}

The isolation and identification of the isolated colonies in different culture media was performed using standard bacteriological procedures as described by Buxton and Fraser (1977). The representative bacterial colonies were characterized morphologically using Gram's stain described by Merchant and Packer (1967).

\section{Motility test}

The motility test was performed to differentiate motile and non-motile bacteria isolated from different suspected bacteriological samples according to the method described by Cowan (1985).

\section{Hemolytic activity}

All the strains were tested for hemolysis on bovine BA plate by incubating them at $37^{\circ} \mathrm{C}$ for 24 hours. Hemolytic patterns were categorized as: Alpha $(\alpha)$ hemolysis: a zone of greenish discoloration around the colony manifested by partial hemolysis. $(\beta)$ Hemolysis; complete clear zone of hemolysis around the colony and Gamma ( $\gamma$ ) hemolysis: no detectable hemolysis.

\section{Reactions of the organisms in TSI agar slants}

Triple sugar iron agar (TSI agar) was used to detect the lactose, sucrose and dextrose fermenters and also the bacteria which produce hydrogen sulphide. The organisms were seeded over the surface of the slants and stabbed into the butt where the cases changes after an incubation of 24 hours at $37^{\circ} \mathrm{C}$. 


\section{Sugar fermentation test}

The sugar fermentation test was performed using five basic sugars (e.g., dextrose, sucrose, lactose, maltose, and mannitol) separately according to the procedure described by Ryan and Ray (2004).

\section{Catalase test and coagulase test}

Slide catalase and tube catalase tests were performed to differentiate the isolated bacteria according to the procedure described by Cheesbrough (2006). The results of coagulase test positive and negative samples were recorded according to the standard method described from Health protection agency (2005).

\section{Indole test, Methyl red test and Voges-Proskauer test}

These tests were used to differentiate the isolated bacteria from various bacteriological samples collected from sick and dead birds. The test was performed and result was interpreted according to the standard procedure described by Cheesbrough (2006).

\section{Agar slant and 25\% sterile buffered glycerin}

The organisms isolated were inoculated into the nutrient agar slants to preserve them as a stock culture for few months and in $25 \%$ sterile buffered glycerin for several years at $-80^{\circ} \mathrm{C}$ without any deviation of their original characters (Buxton and Fraser, 1977).

\section{RESULTS AND DISCUSSION \\ Clinical diagnosis \\ Colibacillosis}

About 16 (34\%) of the 47 suspected broiler chickens and 28 (31.82\%) of the 88 affected layer chickens were diagnosed as colibacillosis. The most obvious clinical signs were diarrhoea, depression, soiling of cloaca with semisolid cheesy material, respiratory distress (coughing, sneezing), reduced egg production, loss of condition and death. Similar types of findings were described by Calnek et al. (1997), Chauhan, (2003), Vegad and Katiyar, (2003). Recorded postmortem lesions were omphalitis and fluid accumulation in the peritonial cavity of chicks (Plate 1), dark-colored swollen liver and spleen, fibrinopurolent airsacculitis, pericarditis, perihepatitis (Plate 2), hemorrhagic enteritis (Plate 3) with fluid accumulation in ligated intestinal loops (Plate 4) and diarrhea, arthritis, panophthalmitis, and salpingitis in some cases. These findings of the present study agree with the findings of Nakamura et al. (1985).

\section{Salmonellosis}

Out of 47 broilers and 88 layer suspected chickens, 11 (23.40\%) broiler and 16 (18.18\%) layer chickens were clinically diagnosed as Salmonellosis. Most common clinical signs of Salmonellosis were drowsiness, huddled together, poor growth, chalky white diarrhoea with pasted vent, dehydration, reduced egg production and death which agreed with the findings of Calnek et al. (1997). After necropsy the gross lesions were observed as peritonitis, unabsorbed yolk (Plate 5); discrete, small, white, necrotic foci in the liver which became swollen and fragile with distinctive coppery bronze sheen on the surface (Plate 6); turbid yellow color fluids in the peritoneal cavity and irregular, haemorrhagic ova with prominent thicken stalks (Plate 7). These findings were supported by Calnek et al. (1997).

\section{Fowl cholera (FC)}

Out of 47 broiler and 88 layer chickens, 2 (4.25\%) broiler and 11 (12.50\%) layer chickens were clinically diagnosed as FC. The common clinical signs were nasal and ocular discharge, darkened head and combs, diarrhoea, ruffled feathers, increased respiratory rate, swollen wattles, high temperatures and lameness which agreed with the findings of Khan et al. (1997) and Rahman et al. (2004). In the postmortem examination gross lesions were swollen liver with hemorrhages, focal necrosis on the liver (Plate 8) and spleen; increased pericardial and peritoneal fluids, hemorrhages in pericardial band, hyperemia of the upper intestine (Plate 9), petecheal hemorrhage on the coronary band of heart muscle and fat (Plate 10), purulent pneumonia and yolk peritonitis, in chronic fowl cholera swelling of affected tissues like joints, sternal bursae, and exudates from conjunctivae. Similar findings were described by Calnek et al. (1997) and Shivachandra et al. (2005). 




Plate 1. Fibrinopurolent fluid accumulation in the peritonial cavity of 13-day-old broiler chicken affected with colibacillosis



Plate 3. Fluid accumulation intestinal loops of 18 day old broiler chicken affected with colibacillosis.

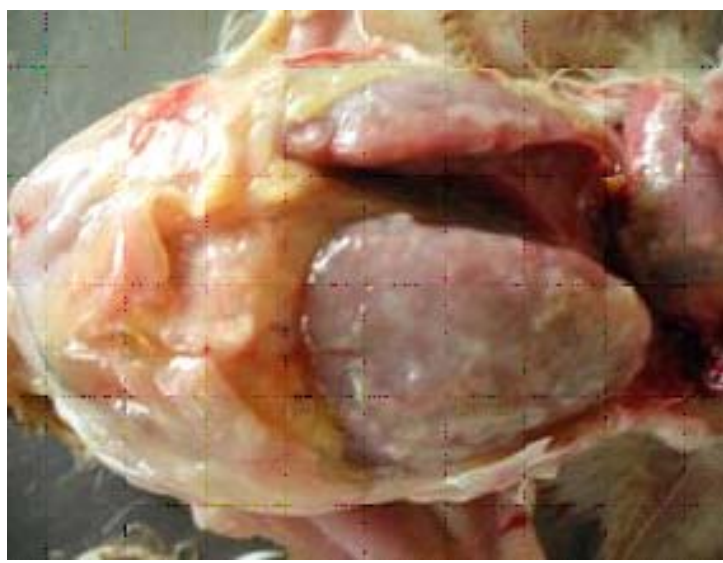

Plate 2. Fibrinopurolent airsacculitis, pericartis, perihepatitis of 13-day-old broiler chicken affected with colibacillosis



Plate 4. Cut section of intestine of colibacillosis infected 23 day old broiler chickens showing enteritis 
Common bacterial diseases of broiler and layer chickens



Plate 5. A 3-day-old broiler chicken showing peritonitis and unabsorbed yolk sac affected with salmonellosis

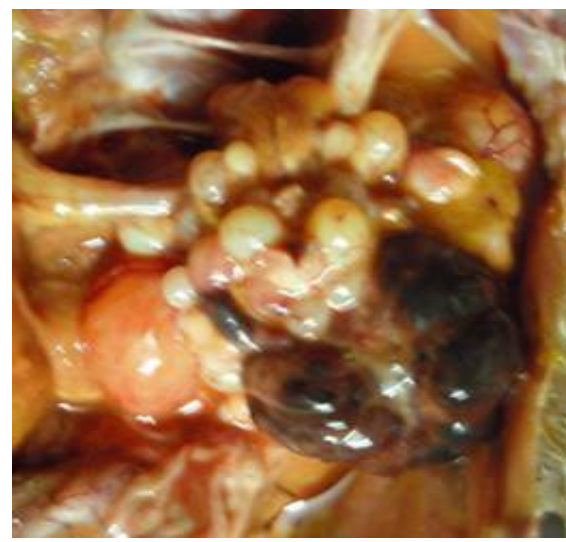

Plate 7. Irregular and haemorrhagic ova with prominent thicken stalks of salmonella affected layer chicken of 13 week age

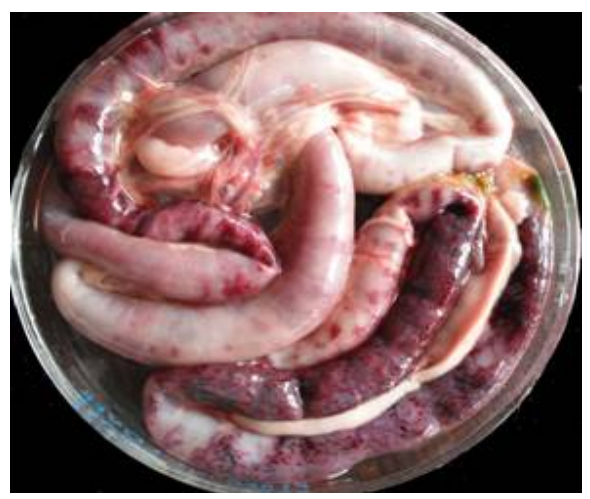

Plate 9. Hyperemia of the upper intestine of layer chicken of 24 week age affected with Fowl Cholera

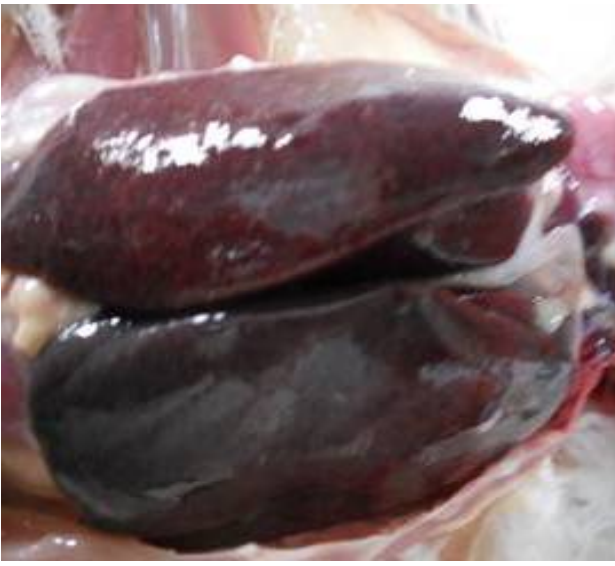

Plate 6. Layer chicken of 25 week age having swollen and dark liver with coppery bronze sheen affected with salmonella

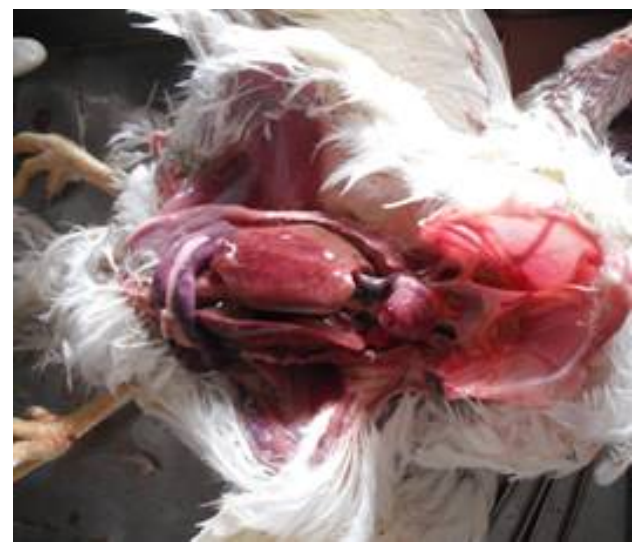

Plate 8. Swollen and haemorrhagic liver of 33 weeks aged layer chicken affected with Fowl Cholera



Plate 10. Hemorrhages in pericardial band of Fowl Cholera infected layer chicken of 29 week age 


\section{A. K. M. Rakibul Hasan and others}

\section{Results of laboratory diagnosis of bacterial diseases Colibachtosis}

On the basis of cultural and biochemical properties of the isolates, 34 chickens (12 broilers and 22 layers) out of 44 (16 broilers and 28 layers) clinically diagnosed colibacillosis cases, were positive for $E$. coli.

\section{Cultural examination}

The organisms were isolated from the samples on different agar media, where smooth, large, colorless, circular colonies on blood agar, rose pink colonies with precipitate on MacConkey agar, yellow to greenish-yellow colonies surrounded by an intense yellow-green zone on BGA, the blue-black colonies with characteristic green sheen on EMB agar, slight growth and pink to rose-red colonies with precipitate on SS agar media and yellow colored slant with the accumulation of gas bubbles in the butt on TSI agar slant were recorded which was corresponded with the findings of others (Baron, 1996; Levinson and Jawetz, 2001).

\section{Gram's staining and motility test}

The Isolated organisms of different pure culture media were gram-negative, pink colored, small rod shaped and arranged in single, pairs or short chain which supports the findings of Merchant and Packer (1967), Cheesbrough (1984), Buxton and Fraser (1977). The test organisms were found to be motile which is similar with the findings of Buxton and Fraser (1977).

\section{Biochemical tests}

The organisms produced both acid and gas by fermenting glucose, dextrose, maltose, lactose, sucrose and mannitol. Acid production was indicated by the color change of the sugar media from reddish to yellow and the gas production was noticed by the presence of gas bubbles in the inverted Durham's tube (Buxton and Fraser, 1977; Thomas, 1988). The organisms were positive to methyl red and negative to voges-proskauer reactions (Thomas, 1988). Hydrogen sulphide was not produced but Catalase and Indole test were positive which support the findings of Buxton and Fraser, 1977; Cheesbrough 1984. The result has been shown in Table 1.

\section{Salmonellosis}

On the basis of cultural and biochemical properties of the isolates, 18 (7 broilers and 11 layers) chickens of 27 (11 broilers and 16 layers) clinically diagnosed salmonella cases, were positive for salmonella infection.

\section{Cultural examination}

The organism (Salmonella spp.) were grown on different media where they produced turbidity in nutrient broth; circular, smooth, opaque and translucent colonies on NA, colorless colonies with black centers on SS agar, pale pink color colonies against a pinkish background on BGA; Pale, smooth, transparent and raised colonies on MacConkey agar; large, colorless colonies on EMB agar media and on TSI agar slant Salmonella gallinarum produced black colony converting the slant to yellow color whereas Salmonella pullorum produced white colony and the slant converted to pink color which was corresponded with the findings of others (Buxton and Fraser 1977; Cheesbrough, 1984).

\section{Gram's staining and motility test}

The test organisms were gram-negative short, straight rod and mostly occurred singly occasionally paired which also corresponded with morphological characters of Salmonella as described by several authors (Cheesbrough, 1984). Salmonella gallinarum and Salmonella pullorum were non-motile whereas other poultry Salmonella spp. were found to be motile (Cheesbrough, 1984 and Christensen et al., 1993).

\section{Biochemical tests}

Salmonella spp did not ferment lactose and sucrose but fermenting dextrose and mannitol produced both acid and gas which was corresponded with the findings of others (Dhruba et al., 1999; Young et al., 2003). Salmonella gallinarum produced only acid whereas Salmonella pullorum produced both acid and gas and all of the isolates were indole negative, methyl red positive and VP negative which are special biochemical characters for Salmonella spp. that previously suggested by a number of scientists (Christensen et al., 1993; Robinson et al., 2000; Sujatha et al., 2003). The result has been shown in Table 1. 


\section{Fowl cholera}

According to the cultural and biochemical properties of the isolate, 8 (only layers) chickens of 13 (2 broiler and 11 layers) clinically diagnosed fowl cholera cases, were positive for $P$. multocida infections.

\section{Cultural examination}

After overnight incubation the organism ( $P$. multocida) produced diffused turbidity in nutrient broth; round, flat colonies of sticky, mucoid consistency on NA; round, grayish and mucoid colony with musty odour on BA media, slight growth with colorless colonies on EMB Agar media and no growth occurred on MacConkey agar which was corresponded with the findings of others (Buxton and Fraser 1977; Cheesbrough, 1984).

\section{Gram's staining and motility test}

The microscopic examination of Gram's stained smears from NA and BA revealed gram-negative small rod or coccobacilli and arranged in single, paired or occasionally in short chain which was similar with the findings of others (Calnek et al., 1997; Woo and Kim, 2006). The isolates of Pasteurella multocida were found to be nonmotile when observed under microscope after hanging drop slide preparation that support the findings of Calnek et al. 1997.

\section{Biochemical tests}

The isolates fermented dextrose, sucrose, mannitol and produced only acid which was corresponded with the findings of others (Merchant and Packer, 1967). Both the MR and VP tests were negative but catalase, hydrogen sulphide and indole tests were positive which are almost similar with the findings of Buxton and Fraser 1977. The result has been shown in Table 1 .

Table 1. Biochemical properties of the bacterial isolates

\begin{tabular}{|c|c|c|c|c|c|c|c|c|c|c|}
\hline \multirow{2}{*}{ Bacterial isolates } & \multicolumn{5}{|c|}{ Carbohydrate fermentation tests } & \multirow{2}{*}{$\begin{array}{l}\text { MR } \\
\text { test }\end{array}$} & \multirow{2}{*}{$\begin{array}{l}\mathrm{VP} \\
\text { test }\end{array}$} & \multirow{2}{*}{$\begin{array}{c}\text { Indole } \\
\text { test }\end{array}$} & \multirow{2}{*}{$\begin{array}{c}\text { Catalase } \\
\text { test }\end{array}$} & \multirow{2}{*}{$\begin{array}{c}\mathrm{H}_{2} \mathrm{~S} \\
\text { production }\end{array}$} \\
\hline & DX & ML & $\mathrm{L}$ & SU & $\mathrm{MN}$ & & & & & \\
\hline Escherichia coli & $\mathrm{AG}$ & $\mathrm{AG}$ & $\mathrm{AG}$ & $\mathrm{AG}$ & $\mathrm{AG}$ & +ve & -ve & +ve & +ve & -ve \\
\hline Salmonella spp. & $\mathrm{AG} / \mathrm{A}$ & -ve /A & -ve & -ve & $\mathrm{AG} / \mathrm{A}$ & +ve & -ve & -ve & +ve & +ve \\
\hline $\begin{array}{c}\text { Pasteurella } \\
\text { multocida }\end{array}$ & $\mathrm{AG}$ & -ve & -ve & A & A & -ve & -ve & +ve & +ve & +ve \\
\hline
\end{tabular}

Legends: $\mathrm{DX}=$ Dextrose, $\mathrm{ML}=$ Maltose, $\mathrm{L}=$ Lactose, $\mathrm{SU}=$ Sucrose, $\mathrm{MN}=$ Mannitol, $\mathrm{A}=$ Acid, $\mathrm{AG}=\mathrm{Acid}$ and gas, + ve $=$ Positive, - ve $=$ Negative, $\mathrm{MR}=$ methyl red and VP = Voges-Proskauer.

\section{Comparison between clinical and laboratory diagnoses}

Out of 47 broiler chickens which were brought under this study, 16 were clinically diagnosed as colibacillosis, 11 as salmonellosis and 2 as FC, whereas from those clinically diagnosed samples, 12 were confirmed as colibacillosis, 7 as salmonellosis and none of the sample was positive for FC (Table 2) in the laboratory. Out of the 88 layer chickens which were brought under this study, 28 were clinically diagnosed as colibacillosis, 16 as salmonellosis and 11 as FC, whereas from those clinically diagnosed samples, 22 field samples were confirmed as colibacillosis, 11 as salmonellosis and 8 as FC (Table 2) in the laboratory. The result showed that all the clinically diagnosed diseases were not positive in laboratory. This is due to the similarity of signs and postmortem findings of different diseases which can not differentiate the diseases accurately which supports with the findings of Banda, 2002.

Table 2. Comparison between the clinical and laboratory diagnoses of different samples

\begin{tabular}{|c|c|c|c|c|}
\hline \multirow{3}{*}{ Name of disease } & \multicolumn{4}{|c|}{ Number of positive cases } \\
\hline & \multicolumn{2}{|c|}{ Broiler } & \multicolumn{2}{|c|}{ Layer } \\
\hline & Clinical Diagnosis & $\begin{array}{c}\text { Laboratory } \\
\text { Diagnosis }\end{array}$ & $\begin{array}{c}\text { Clinical } \\
\text { Diagnosis }\end{array}$ & $\begin{array}{c}\text { Laboratory } \\
\text { Diagnosis }\end{array}$ \\
\hline Colibacillosis & 16 & 12 & 28 & 22 \\
\hline Salmonellosis & 11 & 7 & 16 & 11 \\
\hline Fowl cholera & 2 & 0 & 11 & 8 \\
\hline Total & 47 & 34 & 88 & 67 \\
\hline
\end{tabular}




\section{A. K. M. Rakibul Hasan and others}

From the present study, it may be concluded that mixed bacterial infections both in the broiler and layer chickens are difficult to confirm accurately by clinical diagnosis without laboratory diagnosis (organism isolation, identification and characterization) using Gram's staining, cultural studies and biochemical tests which are most reliable, accurate, economic method for the confirmatory diagnosis of different bacterial diseases of poultry.

\section{REFERENCES}

1. Banda A (2002). Characterization of field strains of Infectious bursal disease virus (IBDV) using molecular techniques. Dissertation (Doctor of Pholosophy).

2. Barens JH and Gross WB (1997). Colibacillosis, in: Diseases of poultry. Edited by: Calnec, B. W. $9^{\text {th }}$ Ed. Iowa University Press. Iowa, U.S.A.

3. Baron S (1996). Medical Microbiology (Fourth Edition). Addision-Wesley publishing compy. pp. 227-513.

4. Biswas PK, Uddin GM, Barua H, Roy K, Biswas D, Ahad A and Debnath NC (2006). Causes of loss of Sonali chickens on smallholder households in Bangladesh. Preventive Veterinary Medicine 76(3-4): 185-195.

5. Buxton A and Fraser G (1977). Animal Microbiology. Vol. 1. Blackwell Scientific Publications, Oxford, London, Edinburg, Melbourne. pp. 93-157.

6. Calnek BW, Barnes HJ, Beard CW, McDougald LR and Saif YM (1997). Diseases of Poultry. $10^{\text {th }}$ edition. Iowa State University Press, Ames, Iowa. pp. 131-140.

7. Charlton BR (2000). Bacterial Diseases. In: Avian Disease Manual. 5th edn., The American Association of Avian Pathologists. USA.

8. Chauhan RS (2003). Bacterial Diseases. In: Illustrated Special Veterinary Pathology. International Book Distribution Co., UP, India.

9. Cheesbrough M (1984). Medical laboratory Mannual for Tropical Countries. 0 edition. Vol-11. Microbiology, Chapter 35, London English Language Book Society. pp. 225-392.

10. Cheesbrough M (2006). District Laboratory Practice in Tropical Countries. $2^{\text {nd }}$ edition. London English Language Book Society. pp. 100-194.

11. Choudhury KA, Amin MM, Rahman A and Ali MR (1985). Investigation of natural outbreak of fowl cholera. Bangladesh Veterinary Journal 19(1-4): 49-56.

12. Christensen JP, Olsen JE, Hansen HC and Bisgaard M (1993). Ribotypes of Salmonella enterica serovar Gallinarum biovars gallinarum and pullorum. Avian Pathology. 22: 725-738.

13. Cowan ST (1985). Cowan and Steel's manual for identification of medical bacteria. $2^{\text {nd }}$ edition. Cambridge University press, Cambridge, London. pp. 138-139.

14. Das PM, Rajib DMM, Noor M and Islam MR (2005). Relationship analysis on the proportional incidence of poultry disease in greater Mymensingh of Bangladesh. In: Proceeding of the $4^{\text {th }}$ International Poultry Show \& Seminar organized by World's Poultry Science Association, Bangladesh Branch. pp. 35-39.

15. Dhruba C, Chakrabory G and Chatterjee A (1999). Studies on avian salmonellosis in West Bengal. Indian Journal of Animmal Science 69(1): 1-3.

16. Haider MG, Rahman MM, Hossain MM, Rashid M, Sufian MA, Islam MM and Haque AFMH (2004). Production of formalin killed fowl typhoid vaccine using local isolates of Salmonella gallinarum in Bangladesh. Bangladesh Journal of Veterinary Medicine 5(1/2): 33-38.

17. Health Protection Agency (HPA) (2005). Coagulase test. National Standard Method. BSOP TP 10 (3): 1-9.

18. Hofstad MS, John BH, Celnec BW, Reid WN and Yoder JHW (1984). Diseases of poultry. Eighth Edition. Panima Education Book Agreny, New Delhi. Ind, pp. 65-123.

19. Khan M, Das PM, Choudhury KA and Islam MR (1997). Pathology of experimentally induced fowl cholera in chickens. Bangladesh Veterinary Journal. 31:28-34

20. Levinson W and Jawetz E (2001). Medical Microbiology and Immunology. 6th edn., McGraw-Hill International, Toronto.

21. Merchant IA and Packer RA (1967). Veterinary bacteriology and virology. $7^{\text {th }}$ edition. The Iowa State University Press, Ames, Iowa, USA. pp. 211-305.

23. Nakamura K, Maecla M, Imada Y, Imada,T and Sato K (1985). Pathology of spontaneous colibacillosis in a broiler flock. Veterinary Pathology 22: 592-597. 
24. Rimler RB (1994). Presumptive identification of Pasteurella multocida serogroups A, D, and F by capsule depolymerisation with mucopolysaccharidases. Veterinary Record 134: 191-192.

25. Rimler RB and Glisson JR (1997). Diseases of poultry, 1Oth ed. Iowa State University Press, Ames, Iowa. pp. 143-160.

26. Robinson H, Mdegela MGS, Yongolo U, Minga M and Johin E (2000). Molecular epidemiology of Salmonella gallinarum in chickens in Tanzania. Avian Pathology 29: 457-463.

27. Ryan KJ and Ray CG (2004). Sherris Medical Microbiology $4^{\text {th }}$ edition. McGraw Hill. ISBN 0838585299. pp. 232-390.

28. Samad MA (2000). An overview of livestock research reports published during the twentieth century in Bangladesh. Bangladesh Veterinary Journal 34: 53-149.

29. Shivachandra SB, Kumar AA, Saxena MK, Srivastava SK and Singh N (2005). Detection of P. multocida in experimentally infected embryonated chicken eggs by PCR assay. Indian Journal of Experimental Biology 44(4): 321-324.

30. Stebbins M, Berkhoff HA.and Corbett WT (1992). Epidemiological studies of congo red E. coli in broiler chickens. Canadian Journal of Veterinary Research 56(3): 220-225.

31. Sujatha K, Dhanalakshmi K and Rao AS (2003). Antigenic characterization and antibiotic sensitivity of field isolates of Salmonella gallinarum. Indian Veterinary Journal 80(10): 965-968.

32. Thomas CGA (1988). Gram-negative bacilli. Medical Microbiology. $6^{\text {th }}$ edition. Bailliere, Tindall. pp. 273274.

33. Vegad JL and Katiyar AK (2003). Bacterial Diseases. In: A Textbook of Veterinary Special Pathology (Infectious Diseases of Livestock and Poultry). International Book Distribution Co., UP, India.

34. Woo YK and Kim JH (2006). Fowl cholera outbreak in domestic poultry and epidemiological properties of P. multocida isolate. Journal of Microbiology 44(3): 344-353.

35. Young JL, Kim KS, Kwon YK and Tak RB (2003). Biochemical characteristics and antimicrobials susceptibility of Salmonella gallinarum isolated in Korea. Journal of Veterinary Science 4(2): 161-166. 